Finanse, Rynki Finansowe, Ubezpieczenia nr 3/2017 (87), cz. 1

\title{
System kontroli wewnętrznej w audycie wewnętrznym procesów innowacyjnych
}

\author{
Katarzyna Piotrowska*
}

\begin{abstract}
Streszczenie: $\mathrm{Cel}$ - Celem artykułu jest próba określenia roli jaką powinien pełnić efektywnie funkcjonujący system kontroli wewnętrznej w usprawnianiu realizacji procesów innowacyjnych.

Metodologia badania - Na potrzeby artykułu wykorzystano krytyczną analizę literatury przedmiotu i regulacji prawnych, obserwację praktyki gospodarczej w zakresie realizacji, kontroli i audytu procesów innowacyjnych (realizacja projektów badawczo-rozwojowych w programach ramowych Unii Europejskiej).

Wynik - Efektem prowadzonych badań jest określenie zasad opracowania procedur kontroli wewnętrznej celem zapobiegania nieprawidłowościom pojawiającym się przy realizacji procesów innowacyjnych.

Oryginalność/wartość - Brak kompleksowego opracowania dotyczącego sposobu organizacji systemu kontroli wewnętrznej w zakresie działalności innowacyjnej determinuje zasadność prowadzenia badań w niniejszym obszarze. Artykuł ma charakter aplikacyjny, a jego wyniki mogą być wykorzystane w procesie opracowania procedur kontroli wewnętrznej w podmiotach realizujących projekty innowacyjne.
\end{abstract}

Słowa kluczowe: system kontroli wewnętrznej, proces innowacyjny, identyfikacja ryzyka, mechanizmy kontrolne, procedury kontroli wewnętrznej

\section{Wprowadzenie}

Prowadzenie działalności gospodarczej jest procesem złożonym, wymagającym przyjęcia przez zarządzającego określonej strategii działania nie tylko na poziomie strategicznym, ale i operacyjnym. Podlegające ciągłym zmianom otoczenie organizacji oraz silna konkurencja na rynku zmusza zarządzającego do prowadzenia działalności w sposób elastyczny. Polega to na umiejętności przystosowywania się organizacji gospodarczej do otoczenia oraz wprowadzania zmian, dzięki którym organizacja zdobywa bądź utrzymuje przewagę konkurencyjną. W praktyce oznacza to podejmowanie działań o charakterze innowacyjnym, polegającym na stosowaniu z sukcesem nowych pomysłów. Uruchamia to proces decyzyjny determinujący zmiany w organizacji gospodarczej, których efektywność musi podlegać ciągłej kontroli. Kontrola jako element procesu zarządzania stanowi instrument kierownictwa, dzięki któremu istnieje możliwość nadzorowania podejmowanych działań i ich rezultatów. Umożliwia to szybkie reagowanie w sytuacji zagrażającej realizacji procesu innowacyjnego, zabezpieczające organizację przed niekorzystnymi rezultatami.

\footnotetext{
* dr Katarzyna Piotrowska, Uniwersytet Ekonomiczny we Wrocławiu, KTRiAF, Wydział Zarządzania, Informatyki i Finansów, e-mail: katarzyna.piotrowska@ue.wroc.pl.
} 
Niezbędnym elementem sprawnego zarządzania jest efektywny system kontroli wewnętrznej, którego zadaniem jest minimalizowanie ryzyka pojawiającego się na każdym etapie realizacji procesu innowacyjnego. Opracowując procedury kontroli wewnętrznej, wyznaczając osoby odpowiedzialne za sprawdzanie stopnia realizacji procesów innowacyjnych, ustalając zakres i sposób przeprowadzania działań kontrolnych, zarządzający przyczynia się do usprawniania realizacji procesów innowacyjnych.

Celem artykułu jest próba określenia roli jaką powinien pełnić efektywnie funkcjonujący system kontroli wewnętrznej w usprawnianiu realizacji procesów innowacyjnych. Na potrzeby artykułu wykorzystano krytyczną analizę literatury przedmiotu i regulacji prawnych, obserwację praktyki gospodarczej w zakresie realizacji, kontroli i audytu procesów innowacyjnych (realizacja projektów badawczo-rozwojowych w programach ramowych Unii Europejskiej). Efektem prowadzonych badań jest określenie zasad opracowania procedur kontroli wewnętrznej, w celu zapobiegania pojawiających się nieprawidłowości przy realizacji procesów innowacyjnych. Artykuł ma charakter aplikacyjny, a jego wyniki mogą być wykorzystywane w opracowywaniu procedur kontroli wewnętrznej w podmiotach realizujących projekty innowacyjne. W artykule wskazano także kierunki dalszych badań.

\section{Kontrola wewnętrzna jako element zarządzania}

Realizacja procesów innowacyjnych wymaga sprawnego kierowania, w ramach którego nadzór i kontrola odgrywają znaczącą rolę. Kontrolowanie oznacza ocenę stopnia realizacji celów wyznaczonych na etapie planowania, tym samym umożliwia zarządzającym śledzenie skuteczności organizowania i motywowania oraz podejmowania w razie potrzeb działań korygujących. Podmioty gospodarcze stosują procedury kontrolne do upewnienia się, czy w zadowalającym stopniu osiągają cele i czy racjonalnie wykorzystują posiadane zasoby (Winiarska, 2010, s. 10). Miejsce kontroli w procesie zarządzania działalnością innowacyjną przedstawiono na rysunku 1 .

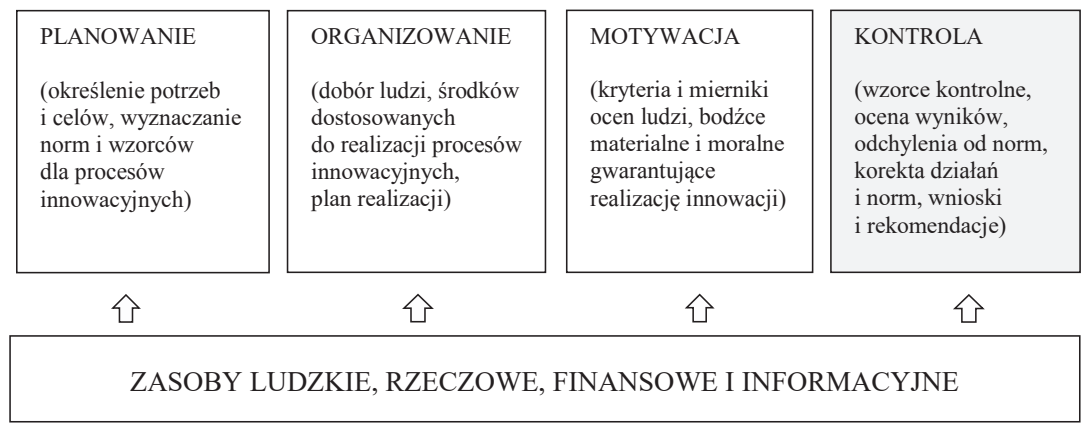

Rysunek 1. System zarządzania procesem innowacyjnym

Źródło: opracowanie własne na podstawie Winiarska (2010), s. 10. 
Kontrola, jako wyodrębniona część systemu zarządzania, jest działaniem, za które odpowiada zarządzający. Podobnie jak przy planowaniu, organizowaniu i motywowaniu, powinna być zasilania zasobami ludzkimi, rzeczowymi, finansowymi i informacyjnymi. Zarządzający mając świadomość, że kontrola jest procesem niezbędnym w usprawnianiu podejmowanych działań, musi ją w odpowiedni sposób zorganizować. Oznacza to konieczność zbudowania skutecznego i efektywnego systemu kontroli wewnętrznej uwzględniającego specyfikę prowadzonej działalności gospodarczej w swojej organizacji. Pojawia się pytanie, czym właściwie jest kontrola wewnętrzna w organizacji gospodarczej i jak należy ją definiować?

Zgodnie z literaturą przedmiotu, kontrola wewnętrzna definiowana jest jako wszechstronnie powiązany system obejmujący wszystkich pracowników przedsiębiorstw sprawujących funkcje nadzoru, pracowników mających obowiązek kontrolowania określonych zagadnień, jak również te osoby, których obowiązki wynikają z przepisów lub poleceń zwierzchnika (Klimas, za: Nadolna, 2009, s. 272). Podobnie definiuje kontrolę wewnętrzną Terebucha podkreślając w niej rolę zarządzającego jako odpowiedzialnego za zorganizowanie kontroli w ramach spójnego systemu, mianowicie - czynności wykonywane w ramach funkcji zarządzania przez zespół kierowniczy przedsiębiorstwa, jak również przez wyznaczone do tego komórki i osoby. Czynności te polegają na sprawdzeniu, za pomocą porównania z ustalonym zadaniem, wydanym zarządzeniem wewnętrznym i obowiązującymi przepisami, legalności, rzetelności i prawidłowości przeprowadzonych w przedsiębiorstwie operacji gospodarczych, zarówno zamierzonych, jak i faktycznie dokonanych, w celu zwiększenia efektywności działania, zapewnienia ochrony własności społecznej oraz przestrzegania obowiązujących norm prawnych i instrukcji wewnętrznych (Terebucha, za: Nadolna, 2009, s. 275). Jest to spójne z kolejną definicją kontroli wewnętrznej, w której kontrolą określono wszystkie te procesy operacyjne i instrukcje, mechanizmy i struktury (organizacyjne i hierarchiczne), przepisy i zarządzenia, inne wymagania, które organizacja wprowadza, żeby jej czynności były możliwie skutecznie zabezpieczone, oraz prowadzone w sposób efektywny, i które razem wzięte stanowią system kontroli danej organizacji (Saunders, za: Nadolna, 2009, s. 272). Kontrolę wewnętrzną rozpatruje się też jako zorganizowany proces i system, w którym uczestniczą pracownicy i kierownictwo jednostki wspomagane nowoczesnym sprzętem organizacyjno-technicznym, bez którego współcześnie trudno skutecznie i efektywnie funkcjonować na rynku (Paczuła, za: Nadolna, 2009, s. 272) $)^{1}$.

W standardach dotyczących kontroli wewnętrznej kontrola jest również przypisywana do kompetencji zarządzającego. Jest to proces kontrolny realizowany przez zarząd organizacji, kadrę menedżerską i pozostałych pracowników w celu umożliwienia uzyskania efektywności i wydajności operacyjnej, wiarygodności sprawozdań finansowych oraz

\footnotetext{
${ }^{1}$ Przegląd definicji kontroli wewnętrznej przedstawiają Kałużny (2008), Winiarska (2010), Nadolna (2009), Szczepankiewicz (2016) i in.
} 
zgodności z przepisami prawa i innymi regulacjami (Standardy kontroli COSO), ewentualnie jako środki funkcyjne, za pośrednictwem których kierownictwo zdobywa pewność, że procesy za które odpowiada, przebiegają w sposób minimalizujący prawdopodobieństwo wystąpienia oszustwa, błędu czy nieekonomicznych lub nieskutecznych praktyk (Standardy kontroli INTOSAI).

Wskazując na powyższe definicje można stwierdzić, że z problematyką kontroli wewnętrznej niewątpliwie związane jest pojęcie mechanizmów kontroli wewnętrznej, które oznaczają wszelkie działania kadry zarządzającej, zarządu lub innych podmiotów podejmowane w celu zarządzania ryzykiem oraz zwiększenia możliwości spełnienia założonych celów. Kadra zarządzająca planuje, organizuje i nadzoruje wykonywanie takich działań, które w odpowiednim stopniu zapewnią osiągnięcie założonych celów (Międzynarodowe Standardy Praktyki Zawodowej Audytu Wewnętrznego). Mechanizmy kontroli wewnętrznej to procesy inicjowane przez kadrę zarządzającą, których zadaniem jest zapewnienie odpowiedniego stopnia zgodności osiągnięcia misji i celów wyznaczonych dla poszczególnych działań i programów organizacji, w powiązaniu z ich efektywnością, bezpieczeństwem, jak również zgodność z zaplanowanymi zasadami i procedurami, przepisami prawa i innymi regulacjami w myśl wartości etycznych. Przygotowanie skutecznego systemu kontroli wewnętrznej dla poszczególnych obszarów działalności organizacji wymaga zapoznania się $\mathrm{z}$ ich specyfiką, w celu zidentyfikowania wszystkich możliwych rodzajów ryzyka wraz z mechanizmami kontrolnymi, co ma szczególne znaczenie dla realizacji procesów innowacyjnych.

\section{Identyfikacja ryzyka w procesach innowacyjnych a procedury kontrolne}

Realizacja procesu innowacyjnego obarczona jest wysokim stopniem ryzyka. Wynika to $\mathrm{z}$ tego, że innowacja jest nowym, oryginalnym rozwiązaniem, wynikającym z procesu poznawczego, z procesu powiększania zasobów wiedzy, znajdującym praktyczne zastosowanie. Jest to proces wieloetapowy, obarczony wysokim poziomem niepewności, wymagający ciągłego nadzoru i pełnej kontroli na wszystkich etapach jego realizacji (Piotrowska, 2016, s. 347-351). Poziom ryzyka i częstotliwość jego wystąpienia jest uzależniona od rodzaju przeprowadzonego procesu innowacyjnego, sposobu i etapu jego realizacji. Nieprzewidywalność i niepowtarzalność procesów innowacyjnych wymaga elastyczności w określeniu rodzajów ryzyka. W celu sprawnego zarządzania procesami innowacyjnymi należy uwzględnić rodzaj ryzyka zidentyfikowany na każdym etapie jego realizacji wraz ze wskazaniem możliwych do zastosowania mechanizmów kontrolnych (tab. 1). 


\section{Tabela 1}

Rodzaje ryzyka i mechanizmów kontrolnych w poszczególnych etapach procesu innowacyjnego

\begin{tabular}{|c|c|}
\hline Etapy innowacji & Rodzaje ryzyka (mechanizmy kontrolne) \\
\hline 1 & 2 \\
\hline Etap koncepcji & $\begin{array}{l}\text { - ryzyko nieprzewidywalności wyniku etapu (tworzenie i inicjowanie burzy mózgów), } \\
\text { - ryzyko zmienności potrzeb otoczenia (diagnoza potrzeb otoczenia), } \\
\text { - ryzyko braku odpowiednio kreatywnych pracowników (szkolenia i program rozwoju } \\
\text { pracowników, systemy motywacyjne), } \\
\text { - ryzyko niedostosowania do potrzeb otoczenia (obserwacja otoczenia), } \\
\text { - ryzyko nieuzasadnionego wydłużania realizacji poszczególnych faz (harmonogram prac), } \\
\text { - ryzyko prawne, finansowe, kadrowe, rzeczowe i niematerialne ograniczające rozpoczęcie } \\
\text { prac (analiza posiadanych zasobów: rzeczowe, niematerialne i ludzkie), } \\
\text { - ryzyko braku nadzoru i kontroli (wskazanie osób odpowiedzialnych, raportowanie), } \\
\text { - ryzyko nadmiernej kontroli ograniczającej kreatywność (program współpracy, ustalenie } \\
\text { zakresu swobody), } \\
\text { - ryzyko wyboru niewłaściwego rozwiązania (analiza ścieżek decyzyjnych wielu } \\
\text { scenariuszy), } \\
\text { - ryzyko ujawnienia pomysłów przez pracowników (umowa o zakazie konkurencyjności) }\end{array}$ \\
\hline Etap badań & $\begin{array}{l}\text { - ryzyko nieprzewidywalności wyniku - koniec procesu (prognozowanie możliwości } \\
\text { dalszych działań), } \\
\text { - ryzyko podejmowanych działań niezgodnych z planem (przypisanie odpowiedzialności), } \\
\text { - ryzyko poniesienia kosztów wyższych niż planowane (kosztorys - określenie zakresu } \\
\text { limitu), } \\
\text { - ryzyko opracowania nierealistycznych planów merytorycznych i finansowych w dalszych } \\
\text { fazach procesu (studium wykonalności procesu), } \\
\text { - ryzyko braku źródeł finansowania (dobór alternatywnych źródeł finansowania), } \\
\text { - ryzyko braku zasobów rzeczowych i niematerialnych (alternatywne źródła zasobów), } \\
\text { - ryzyko utraty pierwszeństwa w badaniach (monitorowanie konkurencji, ochrona } \\
\text { patentowa), } \\
\text { - ryzyko braku potencjału kadrowego (alternatywne źródła, system kar i nagród), } \\
\text { - ryzyko braku nadzoru i kontroli (ustalenie sposobu i częstotliwości przeprowadzania } \\
\text { kontroli - procedury, raportowanie wyników), } \\
\text { - ryzyko braku egzekwowania efektów (przypisanie odpowiedzialności, system kar } \\
\text { i nagród), } \\
\text { - ryzyko przekazania wyników konkurencji (umowy o zakazie konkurencji, } \\
\text { dokumentowanie wyników badań, ochrona prawna) }\end{array}$ \\
\hline Etap rozwoju & $\begin{array}{l}\text { - ryzyko osiągnięcia zadowalającego rezultatu (określenie celów i działań - harmonogram } \\
\text { prac), } \\
\text { - ryzyko niedotrzymania terminów (terminarz prac), } \\
\text { - ryzyko poniesienia nieprzewidzianych kosztów (ustalenie limitu akceptowalności } \\
\text { kosztów, plan zastępczych działań, controlling), } \\
\text { - ryzyko braku nadzoru i kontroli (terminarz kontrolny, dobór technik kontrolnych, } \\
\text { raportowanie wyników), } \\
\text { - ryzyko utraty źródeł finansowania (alternatywne źródła finansowania), } \\
\text { - ryzyko wyprzedzenia przez konkurencję (monitorowanie, ochrona patentowa, umowy), } \\
\text { - ryzyko barier technologicznych, technicznych, organizacyjnych (identyfikacja barier) }\end{array}$ \\
\hline Etap wdrożeń & $\begin{array}{l}\text { - ryzyko dewaluacji planowanych oczekiwań (monitorowanie sytuacji na rynku, } \\
\text { weryfikacja), } \\
\text { - ryzyko nieprzewidzianych kosztów (ustalenie poziomu akceptowalności dodatkowych } \\
\text { kosztów - limity), } \\
\text { - ryzyko braku ochrony patentowej (harmonogram i uwzględnienie w kosztorysie), } \\
\text { - ryzyko barier prawnych (monitorowanie zmian w regulacjach) }\end{array}$ \\
\hline
\end{tabular}




\begin{tabular}{ll}
\hline 1 & 2 \\
\hline $\begin{array}{l}\text { Etap } \\
\text { ekonomiczny }\end{array}$ & ryzyko uzyskania korzyści mniejszych od oczekiwanych lub planowanych (pomiar \\
& dokonań, controlling, opracowanie grupy wskaźników do bieżącego monitorowania \\
& wyników), \\
- & ryzyko ukrytych kosztów, braku analizy kosztów (rachunkowość zarządcza, controlling), \\
- & ryzyko braku analizy uzyskanych efektów (rachunkowość zarządcza, pomiar dokonań), \\
- & ryzyko braku rozliczania osób odpowiedzialnych za proces (regulamin, procedury \\
& egzekwowania wyników) \\
\hline Naśladownictwo - & ryzyko obniżenia konkurencyjności (ochrona prawna, patent), \\
- & ryzyko braku zwrotu zainwestowanych środków (alternatywne źródła odbiorców), \\
- & ryzyko konieczności realizacji nowego procesu innowacyjnego \\
\hline
\end{tabular}

Źródło: opracowanie własne na podstawie zidentyfikowanych rodzajów ryzyka Piotrowska (2016), s. 356-357.

Przedstawione w tabeli 1 propozycje rodzajów ryzyka, wraz z ryzykiem braku kontroli i nadzoru, jak wynika z obserwacji praktyki gospodarczej, można zidentyfikować i minimalizować w procesie innowacyjnym. Należy jednak stwierdzić, że uniwersalny zbiór rodzajów ryzyka nie istnieje, każdy proces przebiega inaczej, wymaga więc indywidualnego podejścia. Niemniej jednak etapy realizacji procesu są w każdym przypadku podobne. Można więc dokonać próby identyfikacji rodzajów ryzyka, uwzględniając etapy procesu, jak również dodatkowo rodzaj innowacji i sposób ich realizacji. Możliwe wydaje się więc opracowanie zbioru wszystkich rodzajów ryzyka, stanowiących swoistą bazę, z której można byłoby dokonywać wyboru odpowiednich rodzajów ryzyka adekwatnych do konkretnego procesu wraz z mechanizmami kontrolnymi. Następnie należałoby dla nich opracować procedury kontroli, w zakresie odpowiedzialności, częstotliwości, rodzajów czynności i sposobu raportowania oraz sposobu eliminowania niepożądanych stanów (korygowanie błędów). Wzorcowy zbiór może usprawnić zarówno sam proces zarządzania, w ramach którego opracowywany jest system kontroli wewnętrznej, jak i pojedyncze czynności kontrolne.

Generalna zasada, obowiązująca w zarządzaniu innowacjami, polega na uzyskaniu przekonania, że zamierzone innowacje są pożądane i potrzebne oraz działaniu w celu ich powstania i udoskonalania. Niezbędny jest do tego sprawnie działający system kontroli wewnętrznej, umożliwiający nadzorowanie procesu innowacyjnego przez zarządzającego na każdym jego etapie - czy przebiega zgodnie z przyjętymi procedurami, w myśl zasady oszczędności, skuteczności i wydajności. Wyzwaniem dla zarządzającego jest udzielenie odpowiedzi na pytanie, jak zbudować sprawnie i skutecznie funkcjonujący system kontroli wewnętrznej dla realizacji procesów innowacyjnych?

\section{Opracowanie systemu kontroli wewnętrznej procesów innowacyjnych}

Opracowanie efektywnego systemu kontroli wewnętrznej w obszarze działalności innowacyjnej wymaga zastosowania tych samych czynności i procedur, które stosowane są w pozostałych obszarach działalności. Każdy zarządzający musi ustalić, kto kontroluje, co 
jest kontrolowane, kto jest objęty kontrolą, pod jakim względem będzie się kontrolować, według jakich kryteriów i jak to zorganizować (Kałużny, 2008, s. 22). Uwzględnienie specyfiki działań innowacyjnych determinuje jednak konieczność działania w sposób bardziej elastyczny, wymagający ciągłej weryfikacji, dostosowania do zmieniających się procesów. Zakres czynności (Winiarska, 2010) podejmowanych w ramach opracowywania systemu kontroli wewnętrznej to:

- sporządzanie planów kontroli poszczególnych komórek organizacyjnych (osobny plan dla każdego podejmowanego procesu innowacyjnego),

- przeprowadzanie kontroli planowych, doraźnych i sprawdzających (ustalenie częstotliwości i rodzaju kontroli),

- analiza zgodności funkcjonujących procedur i przepisów wewnętrznych z obowiązującymi regulacjami (uwzględnienie szerokiego zakresu regulacji),

- analiza odstępstw od obowiązujących procedur, ustalenie i wyjaśnienie ich przyczyn, formułowanie wniosków dotyczących zmian procedur oraz osób odpowiedzialnych,

- przyjmowanie wyjaśnień, oświadczeń czy zastrzeżeń zgłaszanych przez kontrolowane jednostki (na bieżąco, bez zbędnej zwłoki),

- prowadzenie dokumentacji kontrolnej i pokontrolnej (zgodnie z przyjętymi wzorami),

- sporządzanie protokołów z kontroli oraz projektów wystąpień (mogą być podstawą agregowania zdobytej wiedzy i identyfikowania zdobytych umiejętności),

- uczestniczenie w naradach, instruktaż i doradztwo (wskazanie osób),

- przeprowadzanie oględzin i ich dokumentowanie (również inne techniki),

- zabezpieczenie dowodów wymagających interwencji,

- nadzorowanie realizacji wniosków pokontrolnych sformułowanych przez organy nadzoru i kontroli wewnętrznej.

Etapy procesu kontroli działań innowacyjnych przedstawione na rysunku 2 uwzględniają czynności kontrolne wymienione wcześniej. Na rysunku 2 zaprezentowano schemat działania, w ramach którego uwzględniono konieczność: określenia norm wzorcowych i metod pomiaru efektywności podejmowanych czynności, zastosowania ich w działaniach kontrolnych, identyfikowania odchyleń, podjęcia działań korygujących i w razie konieczności modyfikowania lub całkowitego zmieniania norm i metod pomiaru efektywności. Mając na uwadze schemat i rodzaj podejmowanych działań kontrolnych, należy ustalić sposób postępowania $\mathrm{w}$ ramach opracowywania systemu kontroli wewnętrznej dla podejmowanych procesów innowacyjnych, dzięki czemu będzie możliwe usprawnienie ich realizacji, a tym samym zwiększenie efektywności zarządzania. Zarządzający organizacją gospodarczą deklaruje propozycje działań podejmowanych w ramach kontroli procesu innowacyjnego w określonych obszarach. Wyniki poszczególnych etapów realizowanego procesu będą umożliwiały podjęcie decyzji, czy ryzyko dalszej realizacji procesu jest akceptowalne przez zarządzającego i umożliwi osiągnięcie zadowalających rezultatów, czy też skłoni go do przerwania i wycofania się z dalszej jego realizacji. W tym celu zarządzający musi dla zidentyfikowanych rodzajów ryzyka i przyjętych mechanizmów kontrolnych opracować 
procedury kontrolne, następnie wskazać komórki lub stanowiska pracy odpowiedzialne za czynności kontrolne, upoważnione do szybkiego reagowania w sytuacji wystąpienia nieprawidłowości, bądź wskazać odbiorców proponowanych zaleceń lub rekomendacji, propozycje działań kontrolnych, jak również działań korygujących w celu usprawnienia realizowanego procesu innowacyjnego. System kontroli wewnętrznej może obejmować propozycje zakresu obszarów do opracowania, co przedstawiono w tabeli 2.

START

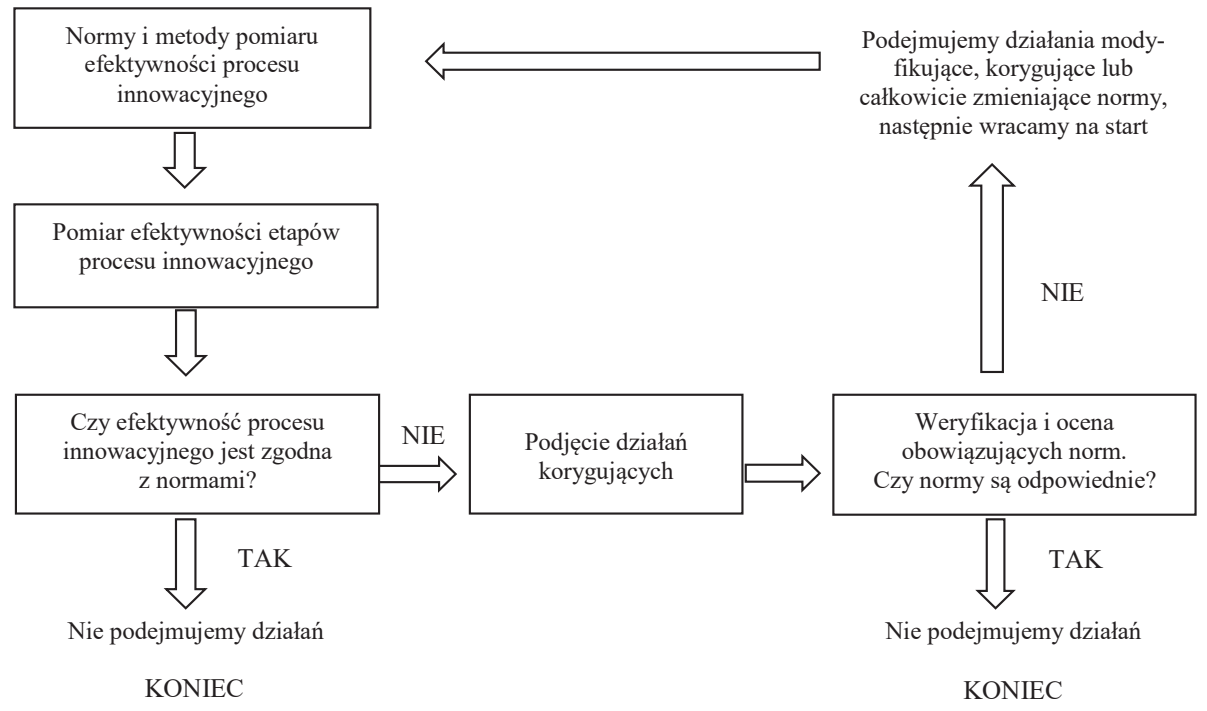

Rysunek 2. Etapy procesu kontroli działań innowacyjnych

Źródło: opracowanie własne na podstawie Winiarska (2010), s. 11.

Zidentyfikowanie wszystkich obszarów kontroli wewnętrznej procesu innowacyjnego (tab. 2) i postępowanie według schematu działania w ramach kontroli wewnętrznej (rys. 2) to niezbędne czynności sprawnego zarządzania. Specyfika procesu innowacyjnego wymusza na zarządzającym działanie elastyczne, wymagające za każdym razem (przy każdej kontroli) weryfikowania otoczenia procesu innowacyjnego, samego procesu innowacyjnego, zmian jakie ze względu na różne czynniki (zewnętrzne, np. nowa technologia, wewnętrzne, np. źródło finansowania) mogą wystąpić i zdeterminować zmiany w procedurach kontrolnych. 


\section{Tabela 2}

Zakres obszarów identyfikowanych w ramach opracowywania procedur kontroli wewnętrznej

\begin{tabular}{lllllll}
\hline & $\begin{array}{l}\text { Identyfika- } \\
\text { cja ryzyka } \\
\text { (mechanizmy } \\
\text { kontrolne) }\end{array}$ & $\begin{array}{l}\text { Procedury } \\
\text { kontrolne }\end{array}$ & $\begin{array}{l}\text { Odpowiedzialność } \\
\text { (komórka, stanowi- } \\
\text { sko, pracownik) }\end{array}$ & $\begin{array}{l}\text { Rodzaj } \\
\text { czynności } \\
\text { kontrolnych } \\
- \text { wyniki } \\
\text { kontroli }\end{array}$ & $\begin{array}{l}\text { Odbiorca } \\
\text { wyników } \\
\text { kontroli }\end{array}$ & $\begin{array}{l}\text { Propozycja } \\
\text { działań } \\
\text { korygują- } \\
\text { cych }\end{array}$ \\
\hline $\begin{array}{l}\text { Etap koncepcji } \\
\text { Etap badań }\end{array}$ & $\ldots$ & $\ldots$ & $\ldots$ & $\ldots$ & $\ldots$ & $\ldots$ \\
Etap rozwoju & $\ldots$ & $\ldots$ & $\ldots$ & $\ldots$ & $\ldots$ & $\ldots$ \\
$\begin{array}{l}\text { Etap wdrożeń } \\
\text { Etap }\end{array}$ & $\ldots$ & $\ldots$ & $\ldots$ & $\ldots$ & $\ldots$ & $\ldots$ \\
ekonomiczny & $\ldots$ & $\ldots$ & $\ldots$ & $\ldots$ & $\ldots$ & $\ldots$ \\
$\begin{array}{l}\text { Etap } \\
\text { naśladownictwa }\end{array}$ & $\ldots$ & $\ldots$ & $\ldots$ & $\ldots$ & $\ldots$ & $\ldots$ \\
\hline
\end{tabular}

Źródło: opracowanie własne na podstawie obserwacji praktyki gospodarczej.

Uwzględniając powyższe, zarządzający powinien przyjąć odpowiedni dla specyfiki swojej organizacji (rodzaj prowadzonej działalności, branża, kompetencje pracowników, strategia innowacyjna, cele i misja, struktura organizacyjna) sposób postępowania. Autorka w tym zakresie proponuje dwa warianty postępowania. Pierwszy polega na opracowaniu kompletnego dla danej sytuacji zbioru zidentyfikowanych rodzajów ryzyka wraz z mechanizmami kontrolnymi, przyjęciu dla każdego ryzyka procedur kontrolnych umożliwiających odpowiedni przebieg kontroli, wskazaniu stanowisk lub osób odpowiedzialnych za poszczególne działania, opracowaniu wzorów raportów pokontrolnych, ustaleniu terminów i częstotliwości kontroli, osób do których raporty z wynikami powinny trafić, o ile jest to możliwe, zaproponowaniu procedur korygujących (naprawczych). Drugie rozwiązanie to opracowanie jedynie zarysu obszarów do scharakteryzowania w ramach procedur kontrolnych przed rozpoczęciem konkretnego procesu innowacyjnego oraz ogólnych zasad postępowania.

W obu wariantach sposób postępowania jest podobny, jednak pierwsza propozycja wymaga szerokiego działania umożliwiającego stworzenie uniwersalnego, kompletnego i pełnego zbioru czynności. Przed realizacją konkretnego procesu innowacyjnego zarządzający musi wybrać z tego zbioru te obszary, które dotyczą danego procesu, odrzucając obszary zbędne, np. nie uwzględnia etapu koncepcji, wówczas nie dobiera czynności z tego zakresu. O ile opracowanie $\mathrm{w}$ tym wariancie systemu kontroli i jego procedur jest czasochłonne i pracochłonne, to same działania przygotowawcze trwają krócej, gdyż korzysta się $\mathrm{z}$ już opracowanych gotowych rozwiązań. Propozycja ta wydaje się przydatna w organizacjach, które ze względu na swoją specyfikę realizują przedsięwzięcia innowacyjne w sposób ciągły i równoległy. $Z$ kolei drugie rozwiązanie, polegające na opracowaniu schematu systemu kontrolnego dla konkretnego, realizowanego procesu i dostosowanie rozwiązania do rzeczywistej sytuacji, wydaje się lepszym wariantem dla organizacji, która procesy 
innowacyjne realizuje rzadko, jako jednorazowe projekty. Zarządzający opracowuje system dla konkretnej sytuacji, co gwarantuje większą trafność rozwiązań. Wymaga jednak poświęcenia większej uwagi i czasu na etapie wstępnym procesu innowacyjnego, opóźniając czy też wydłużając realizację procesu innowacyjnego. Opis procedur postępowania w tym zakresie powinien zostać ujawniony w regulaminie kontroli wewnętrznej. Każda organizacja powinna dokonać wyboru rozwiązania korzystniejszego dla niej ze względu na specyfikę prowadzenia działalności innowacyjnej.

\section{Uwagi końcowe}

Zapewnienie właściwego przebiegu procesów gospodarczych jest zadaniem zarządzającego. Jednym z elementów zarządzania jest kontrola. Organizacja procesu kontroli oznacza konieczność zastosowania rozwiązań systemowych, w ramach których opracowywane są procedury kontrolne. Specyfika działalności innowacyjnej wymaga modyfikowania i dostosowywania obowiązujących procedur do konkretnego działania. Niestety nie jest możliwe budowanie systemu kontroli procesów innowacyjnych bez uwzględnienia ich specyfiki. Zatem, każdy system kontrolny musi cechować się zmiennością, elastycznością, modyfikowalnością procedur, co oznacza możliwość doboru rozwiązań do konkretnego rodzaju innowacji, projektu, etapu jego realizacji, kompetencji pracowników, rozwiązań technologicznych wspierających działania organizacji.

Problematyka przybliżona w artykule wymaga dalszych badań. Autorka wyznacza ich kierunek, konieczność opracowania zbioru rodzajów ryzyka i mechanizmów kontrolnych dla każdego rodzaju innowacji (projektowa, procesowa i organizacyjna) z uwzględnieniem każdego z etapów realizacji (jak w opracowaniu), wraz z procedurami kontrolnymi, osobami odpowiedzialnymi za ich stosowanie, jako gotowej, wzorcowej propozycji, z której organizacja wybiera rozwiązania adekwatne do realizowanego przedsięwzięcia. Zarządzający, w regulaminie kontroli wewnętrznej w części dotyczącej realizacji procesów innowacyjnych, mógłby załączyć bazę wykorzystywaną do opracowania procedur w konkretnym przypadku. Zarządzający musi zadbać o możliwość każdorazowej weryfikacji istniejących procedur (aktualność), celem dostosowania ich do realizacji projektów, zapewniając tym samym osiągnięcie zamierzonego efektu. Dodatkowo daje to możliwość identyfikowania i agregowania powstałej wiedzy, określenia umiejętności i kompetencji pracowników, co umożliwia powiększanie kapitału intelektualnego organizacji gospodarczej.

\section{Literatura}

Kałużny, S. (2008). Kontrola wewnętrzna. Teoria i praktyka. Warszawa: PWE.

Klimas, M. (1997). Podręczna encyklopedia rachunkowości. Warszawa: Poltext.

Moeller, R. (2011). Nowoczesny audyt wewnętrzny. Warszawa: Wolters Kluwer.

Nadolna, B. (2009). System kontroli wewnętrznej w przedsiębiorstwie. Studia i Prace Wydziału Nauk Ekonomicznych i Zarzadzania, 16. 
Paczuła, C. (1998). Kontrola wewnętrzna w zarządzaniu jednostka gospodarczą. Warszawa: Difin.

Piotrowska, K. (2016). Etapy procesu innowacyjnego jako obszaru ryzyka w audycie wewnętrznym. Finanse, Rynki Finansowe, Ubezpieczenia, 6 (84/1), 347-359. DOI: 10.18276/frfu.2016.84/1-30.

Saunders, E.J. (2003). Audyt i kontrola wewnętrzna w przedsiębiorstwie. Częstochowa: Educator.

Szczepankiewicz, E.I. (2016). Kontrola wewnętrzna i audyt wewnętrzny. Poznań: Uniwersytet Ekonomiczny w Poznaniu.

Terebucha, E. (1976). Zasady kontroli wewnętrznej w przedsiębiorstwie. Warszawa: PWE.

Winiarska, K. (2010). Kontrola wewnętrzna w jednostkach gospodarczych. Warszawa: PWE.

\section{INTERNAL CONTROL SYSTEM IN STREAMLINING OF THE INNOVATIVE PROCESSES}

Abstract: Purpose - The purpose of this article is to try to determine the role that an effective internal control system should play in improving the performance of innovative processes.

Design/methodology/approach - For the purposes of this article use of the critical analysis of the literature and law of the regulatory, observation of economic practice in the implementation, control and audit of innovation processes (implementation of R \& D projects within the EU framework programs).

Findings - The result of the research will be the elaboration of internal control procedures in order to prevent irregularities from the implementation of innovative processes.

Originality/value - The lack of comprehensive study on how the internal control system for innovation is organized determines the relevance of research in this area. The article is an application and its results can be used in the process of developing internal control procedures in entities implementing innovative projects.

Keywords: internal control system, innovation process, risk identification, control mechanism, internal control procedures

\section{Cytowanie}

Piotrowska, K. (2017). System kontroli wewnętrznej w audycie wewnętrznym procesów innowacyjnych. Finanse, Rynki Finansowe, Ubezpieczenia, 3 (87/1), s. 19-29. DOI: 10.18276/frfu.2017.87/1-02. 